\title{
The Factors Influencing Fans' Attendance at Football Matches in the Kingdom of Saudi Arabia
}

\author{
By Mohammed Binjwaied ${ }^{*}$ \\ Ian Richards ${ }^{\dagger}$ \\ Lisa-Ann O'Keeffe ${ }^{*}$
}

\begin{abstract}
This quantitative study investigates factors that affect fans' attendance at football stadiums to watch Saudi Premier League (SPL) football matches. We adopted the comparative quantitative research method to compare the significance of the factors, which affect fans' attendance at the football stadiums. Data was collected through a questionnaire. The research was carried out on a sample of 1,506 participants. The factors which have the most effect on fans' attendance are the facilities and services offered by the stadiums and the fact that the seats are not numbered. However, in the case of SPL, external factors have the most impact on the fans' lack of attendance at stadiums in the Kingdom of Saudi Arabia (KSA) including the fact that the matches are televised and the lack of commitment of fans to their favourite teams of SPL. This research also concludes that SPL organisers need to add glamour to SPL events by associating the branding of the league with overseas sporting brands, thereby attracting male fans to these events and improving fan attendance through the use of televised media and online and social media, which would help increase accessibility to fans.
\end{abstract}

Keywords: Fan attendance, Football, Saudi Premier League, Televised matches

\section{Introduction}

Going to the stadium is one of many options available to football fans who want to watch national and international football matches. The sheer number of football fans who watch games on TV make football one of the most popular sports around the world (Szymanski 2005). In the Kingdom of Saudi Arabia (KSA) football attracts the majority of athletes, audiences and sport journalists. Fan attendance is one of the main income sources for football clubs and, therefore, it is necessary to ensure attendance of fans at stadiums (Dietl and Hasan 2007). Fans are not only a source of income for the sports clubs and federations but also provide moral support for the team players. The term "fans", according to Borland and MacDonald (2003), refers to a group of individuals who have a solid emotional attachment with a sport, a team or a player. Gate tickets used to be the only source of revenue for teams and clubs

\footnotetext{
* PhD Student, Leeds Beckett University, UK.

${ }^{\dagger}$ Senior Lecturer, Leeds Beckett University, UK.

${ }^{\ddagger}$ Leeds Beckett University, UK.
} 
until the $20^{\text {th }}$ century. At the turn of the century, new income sources for sports, such as broadcasting rights, became available for sports organisations (Dietl and Hasan 2007). Today, fans can watch and support their favourite teams in a number of ways including TV and through mobile internet. This has resulted in a decrease in the number of fans going to stadiums. Baroncelli and Lago (2006) notes that from 1999 to 2000 there was a strong drop in fans' attendance at the Italian Football League's stadiums. Sports organisations have to develop sound strategies to increase fans' attendance at stadiums. However, other factors such as lack of motivation and undesirable behaviour of sport fans may play a role in the decrease in fans' attendance. Sports researchers have not explored such factors fully (Foster and Washington 2009).

In order to analyse the pattern of attendance at football stadiums it is useful to determine some of the factors which could influence fans' attendance at stadiums and group them on the basis of the fans' behaviour. This will lead to the development of consumer behaviour patterns which will further assist in producing coherent marketing strategies to target and attract fans to stadiums. This area of research has been ignored by researchers in the KSA; therefore, this paper investigates factors affecting fans' attendance at the football stadiums in the KSA.

\section{The Impact of Different Factors on Fans' Attendance}

The studies which have been undertaken on the impact of live broadcasting on the stadium attendance of football fans are limited. There is some weak evidence on the impact of televised matches on fans' attendance based on what the authors deem to be unreliable findings. Borland and MacDonald (2003) highlight some of the difficulties with these observations which provide evidence that if match-day is televised then fans' attendance at the stadium will decrease. Buraimo et al. (2009) concluded that fans' attendance decrease to a lesser extent when a football match is aired on a subscribed TV sports channel; when the football match is broadcast on a freeof-charge TV channels the decrease is much more significant. This indicates that the screening of football matches does impact fans' attendance. According to Buraimo et al. (2010: 472) "The effect of matches televised on subscription television is no different from those matches televised on a pay-per-view basis. The biggest impact results from those matches shown on free-to-air television".

Baimbridge et al. (1995) reached the same conclusion when BskyB started to broadcast rugby football league matches. They found that broadcasting rugby football league matches on BskyB TV had a negative effect on fans' attendance Baimbridge et al. (1995) also examined the effect of broadcasting English FA Premier League football matches on fans' attendance and they found that there was a considerable negative impact on fans' attendance due to the screening of football matches. Furthermore, Kuypers (1996) and Buraimo et al. (2010) highlighted the fact that the day the match is held could also negatively influence fans' attendance. They found out that weekday matches 
attract a lesser number of fans to the stadium than weekend matches. Kuypers (1996) also showed that the reduction in fans' attendance might be exacerbated by weak advertising strategies and might not be due only to the broadcasting of football matches. Buraimo et al. (2010) showed that football matches held on weekends brought about an increase in the number of fans at the stadium. However, Garcia and Rodriguez (2002) disagreed with Kuypers' (1996) findings, pointing out the negative impact of broadcasting the 1992 to 1996 seasons Spanish football matches upon fans' attendance at the stadium. They concluded that, in spite of the fact that only $20 \%$ of the total matches were broadcast, there was a significant influence on attendance.

Allan and Roy (2008) criticised the aforementioned studies for concentrating upon total attendance at matches making it impossible to assess the influence of broadcasting on different groups of attendees. They found that the fluctuation in stadium attendance is caused by fans who buy tickets on the day of the match at the gate of stadium; fans who are season-ticket holders are not as influenced. The literature highlights the relationship between televising matches and reduction in fans' attendance at the stadium; bottom line being that screening of football matches can be a major factor in reducing fans' attendance at the stadium. However, other factors play a part in negatively affecting fans' attendance at stadiums.

Many other factors can influence fan attendance at football stadiums as highlighted in the literature. There appear to be several factors that play an important role in attracting sports consumers to sporting events, including new arenas, give away days, the "superstar factor", record breaking performance and violence (Hoye et al. 2012). Although previous studies have discussed the impact of televised matches on fans' attendance, it cannot be said with certainty that only the proliferation of televised matches has influenced fans' attendance. The aforementioned studies revealed three main elements which encourage football fans to attend stadiums namely achievement seeking, entertainment and stress relief (Beech and Chadwick 2004, Mehus and Osborn 2010). Fallahi et al. (2011) investigated the factors influencing fans of different age groups' attendance at football matches in Iran. They found that the age of the fans also played important part in motivating the fans to attend the football matches at the stadium. For instance, the "under 21 years old" fans displayed more motivation than other groups to go to the stadiums. Likewise, Withey (2013: 67) showed that, "different age groups, gender, and relationship to the university had significant difference as far as their motivation to attend live matches". Wakefield and Sloan (1995) and Yusof and Lee (2008) highlighted the significance of the quality of services available for fans at the stadium as another factor that influences the future attendance of fans.

There are only a few exploratory studies on factors which influence football fans' attendance which have been carried out in the Gulf region, particularly in the KSA. Jumaah (2014) carried out a study regarding the factors that discourage Kuwait fans' attendance at football matches which was published in the Alrai newspaper. This study found that $70 \%$ of participants of the study enumerated a number of reasons which prevented them from 
attending the football matches including the schedule of the matches, stadium facilities, lack of star players, the level of performance in the matches, media development and new technologies, length of time needed to watch the matches, the tickets sale method, promotion, car parking and finally the fact that matches are televised. Alghamdi (2013) stated that most footballers are of the opinion that the environment or facilities of stadiums in the KSA demotivates fans from attending the stadium. He further asserted that SPL matches are organised in spite of the fact that the facilities are not compliant with the standards set by AFC. Alshalash (2013) also explored the factors that influenced fans' attendance at the stadium to watch SPL football matches. He found that there were many entertainment options for youth, which led to a decrease in their attendance in the KSA. However, according to the Saudi Leagues Statistics (SLS), the fans' attendance at stadiums is influenced by the reputation and performance parameters of the football teams and clubs. It showed that the number of fans attending the stadium differs from club to club in each season, which indicates the commitment and loyalty of the fans to the football clubs are important factors affecting the fans' attendance. With regard to the 2014 and 2015 seasons, SLS published a report that the stadium with newly furnished services attracted the highest record number of fans at the stadium to watch football matches. This indicates that the environment and the quality of the services are important influences on the fans' attendance in the KSA (SLstat, n.d.).

This paper presents the factors influencing the fans' attendance at the stadium in the KSA, exposing important findings about key services tied to the stadium. Indirectly, the findings of this study will offer guidelines on new marketing methods which could be used to improve fans' attendance at the stadium in the KSA.

\section{Materials and Methods}

The population framework consists of KSA football fans. The KAS occupies about four-fifths of the Arabian Peninsula, and occupies an area of 2,149,690 Kilometres Square (Alsenaidy and Ahmad 2012). According to the Central Department of Statistics and Information (CDOSI), in 2011, the population of Saudi Arabia reached 27,136,977 million in 2010, and the number of Saudi citizens was 18,707,576 million which is equal $68.9 \%$, while $8,970,670$ were non-Saudis ( $31.1 \%$ of the population). In the case of the football fans, a questionnaire is essential because the size of the sample is large, and the selected consumers must be from different areas (i.e. the main five regions, which are Northern, Western, Eastern, Southern and the Middle of the Kingdom (Figure 1). The researchers also decided that due to numbers, the snowball sampling method would be most appropriate. For the questionnaire sampling the researcher collected data from the fans in different ways; it was sent links via Twitter, Facebook, WhatsApp, Instagram and official clubs forums to football fans who attend stadiums, watch on TV or use new 
technologies in Saudi Arabia. SmartSurvey was selected as a tool to collect online data. The number of samples collected for the survey was 1,506. The samples took from people aged 16 years and above and their gender distribution was match demographic data held about fans in the KSA.

Figure 1. Map of Saudi Arabia

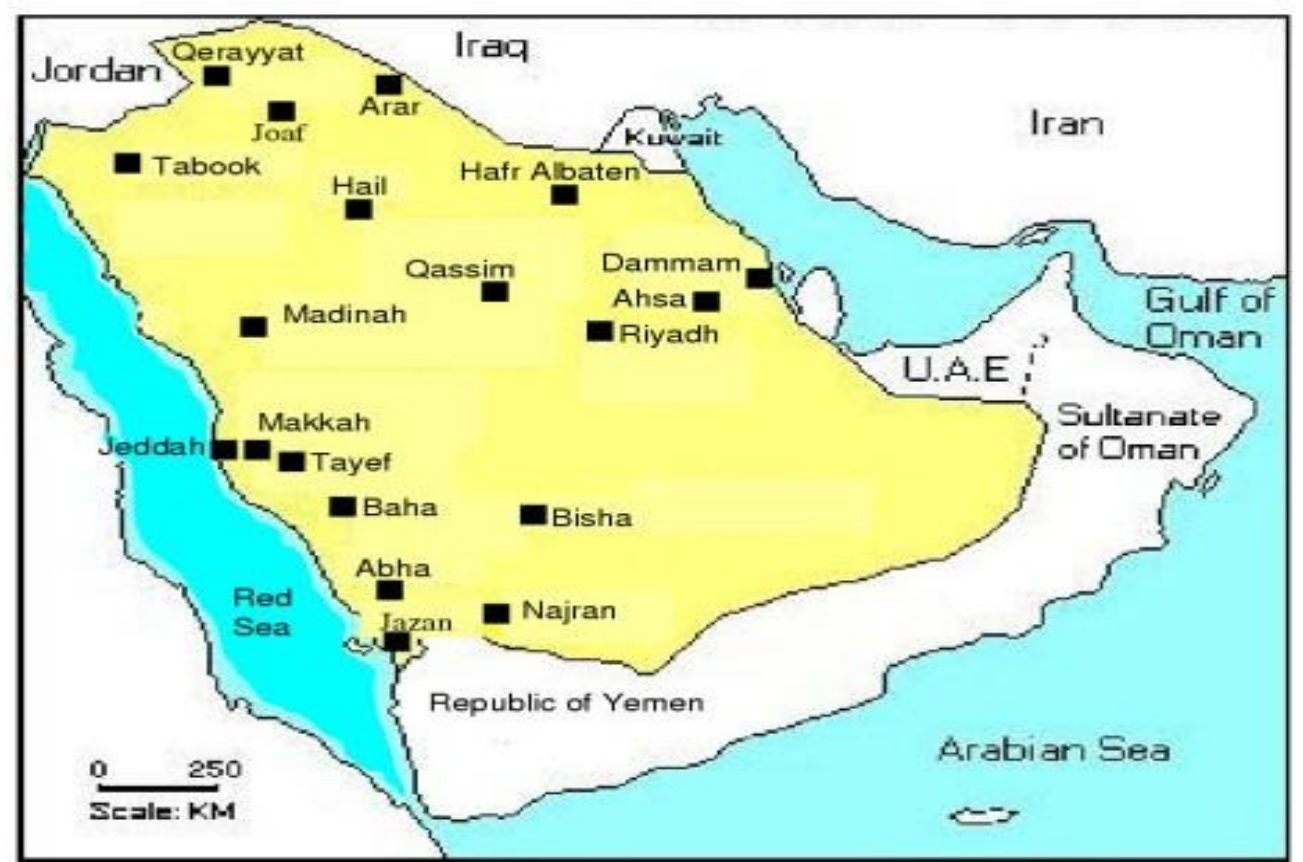

Source: Madani et al. 2004.

A questionnaire consisting of 85 questions was drawn up for the collection of data. In order to design the comprehensive questionnaire, relevant literature was reviewed to identify key factors affecting football fans' attendance at stadiums. The questions in the close-ended interview questionnaire comprised a 5-point Likert scale which required respondents to prioritise the choices given from 1 (strongly agree) to 5 (strongly disagree). The face validity of the questionnaire was established by experts and the reliability of the questionnaire was established through the Cronbach Alpha $=0.823$. The validity of the questionnaire was examined using factor analysis. The population sample consisted of 1,506 respondents, including both males and females within the 16-65 year age range. The sample was chosen using the snowball sampling technique. Questionnaires were distributed to the respondents through social media channels including Facebook, Twitter, Instagram and WhatsApp. In order to obtain the main components of the questionnaire, the orthogonal rotation (Varimax) using the principle component method was applied. Bartlett test of sphericity $\chi^{2}(37119.660)$ was used to examine the inter-correlation of factors. The intercorrelation of factors was considered to be significant with $\mathrm{KMO}>0.5$. For this study independent and dependent variables normality was examined by checking skewness, kurtosis values and visual inspection of its QQ plot. 


\section{Results}

Out of the 1,506 respondents who participated in this study $12.4 \%$ were female and $87.6 \%$ were male. The study received $87 \%$ responses from males and $13.0 \%$ responses from females. The overall response of the female participants was low throughout the regions. In order to understand the bigger picture, the respondents were grouped into age categories. Most of the responses were received from people in the 25-34 year age group (42.4\%), where the male percentage was high $(90.1 \%)$ compared to the female $(9.9 \%)$. The highest percentage of responses by females $(23.4 \%)$ was in the $15-24$ year age group. It was also observed that the percentage of male and female respondents goes down as their age increased. A higher number of responses were received from the higher age categories than the younger age group ranging from 15 to 44 years. The cross tabulation shows that the relationship between the age of the viewers and whether they watch football on TV are both significant factors which have to be taken into account especially for the younger audience, as shown in Figure 2.

Figure 2. Watching Football on TV

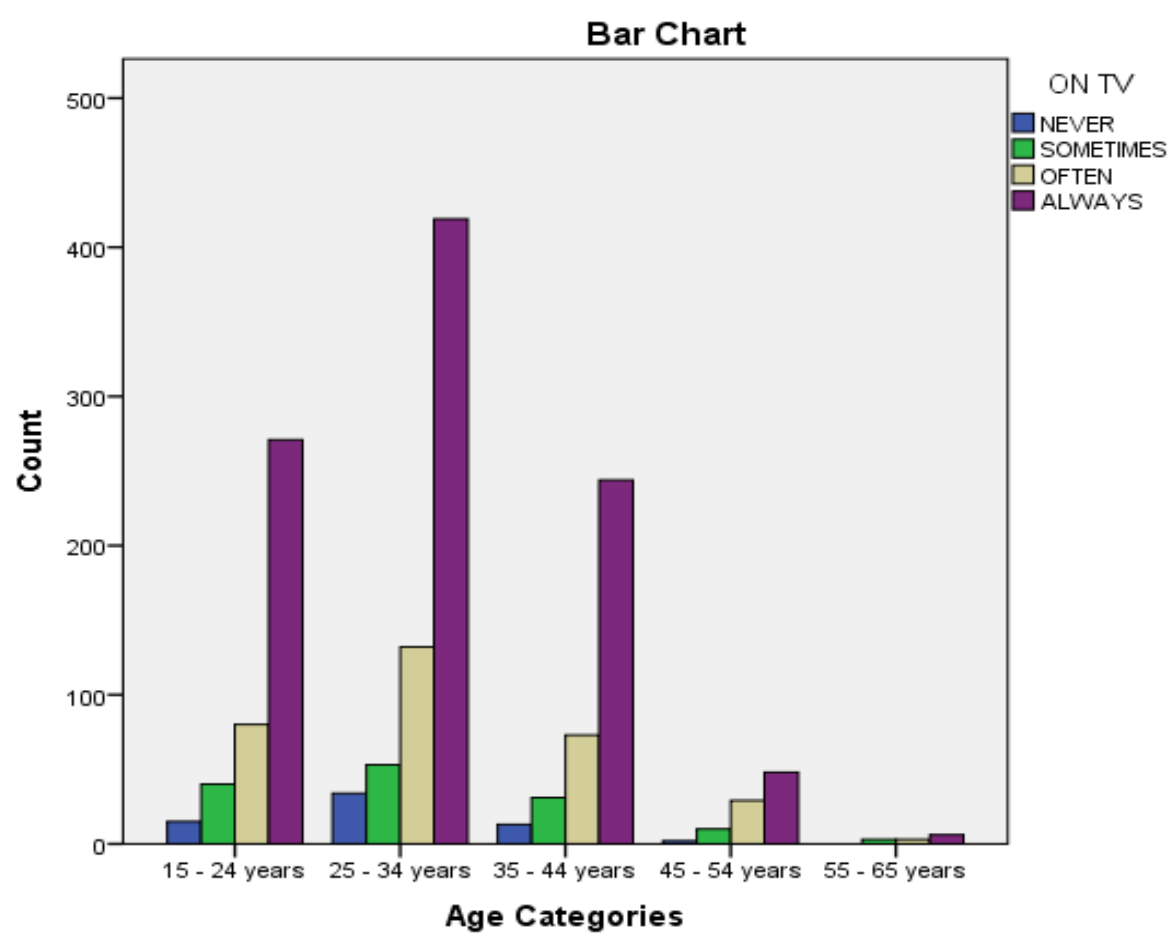

Source: By authors. 


\section{Factors Affecting Attendance at the Stadium}

Broadcasting Media affects Fans' Attendance at the Stadium

Viewer behaviour when watching football in the stadium, on TV and online (using devices such as desktop, laptop, tablet, smartphone) was also investigated.

The mean of the three media shows that on the average viewers prefer to watch football matches on the traditional medium of TV $(M=3.4801$, $\mathrm{SD}=0.82884)$. Viewers chose online medium as their second preference $(\mathrm{M}=1.9914, \mathrm{SD}=0.94601)$. However, the responses of viewers watching football online and on TV were more widely spread than those given by respondents who watched football at the stadium. The mean of each of the three media are given in Table 1 .

Table 1. The Average to Watch Football by TV, Online and Attendance

\begin{tabular}{|l|c|c|c|}
\hline & On TV & $\begin{array}{c}\text { Attendance at } \\
\text { Stadium }\end{array}$ & $\begin{array}{c}\text { Live Football } \\
\text { Matches }\end{array}$ \\
\hline Mean & 3.4801 & 1.5305 & 1.9914 \\
\hline Std. Deviation & 0.82884 & 0.67568 & 0.94601 \\
\hline Total & $\mathbf{1 , 5 0 6}$ & $\mathbf{1 , 5 0 6}$ & $\mathbf{1 , 5 0 6}$ \\
\hline
\end{tabular}

Source: By authors.

Since, on average, watching football at the stadium is low $(M=1.5305$, $\mathrm{SD}=0.67568$ ), the percentages of the three media were calculated. It is evident that $65.6 \%$ of viewers would always prefer to watch football on TV, $1.9 \%$ at the stadium and $11.2 \%$ online. When comparing the percentages of these three media, it is evident that the percentage of viewers who choose to watch football in stadium is very low. Also, $55.4 \%$ of the viewers responded that they would never watch football in the stadium. This figure was alarming and therefore a further data investigation was carried out to look at the factors influencing the fans' attendance at football stadiums.

The questionnaire was designed to investigate the factors affecting the fans' attendance at the stadium. The mean values of the factors are given in Table 2.

Table 2. Factors Affecting Attendance at the Stadium

\begin{tabular}{|l|c|c|}
\hline Factors & Mean & Std. Deviation \\
\hline Environment of stadiums is bad & 4.2769 & 1.07572 \\
\hline Services of stadiums is not good & 4.3805 & 1.00662 \\
\hline lack of respect from fans & 4.0817 & 1.07615 \\
\hline Sport journalists fanaticism & 3.9143 & 1.20352 \\
\hline No buying e-ticket online & 4.0730 & 1.10389 \\
\hline No star players & 3.0651 & 1.21552 \\
\hline No numbered seats & 4.3054 & 1.07879 \\
\hline Poor organisation at entrance gate & 3.9788 & 1.16463 \\
\hline Stadium location & 3.5199 & 1.26803 \\
\hline Not enough car parking space & 3.5239 & 1.24523 \\
\hline Total & \multicolumn{2}{|c|}{$\mathbf{1 , 5 0 6}$} \\
\hline
\end{tabular}

Source: By authors. 
Despite the fact that there is very little difference between the means and standard deviations of the factors listed in the table above, the factors influencing the fans' motivation to go to a stadium could still be ranked in the following order: stadium service, seating not numbered, stadium environment, lack of respect among football fans for each other, non-availability of online purchase method for the sale of tickets and poor organisation at the stadium entrance. The means of "no star players", stadium location and "not enough car parking space" were lower than the other factors so their effect on the fans' attendance at the stadium is negligible.

\section{Fans' Commitment, Support and Loyalty to Football Club Matches}

The results presented above make it evident that a large percentage of respondents watch football through traditional media such as TV. Some football viewers (albeit a very low percentage) watch football matches either online or attendance at stadium. Another possibility is that the viewer numbers might vary for different football matches, based on fan loyalty and support. To distinguish between football matches, fans were asked about their loyalty to Saudi teams and European champion league teams. The data show that $43.5 \%$ of football fans will always watch EU champion league matches. Therefore, there is only small percentage of football fans that are loyal to only Saudi football leagues. These fans will not always watch EU Leagues matches as on average viewers prefer to watch Saudi matches $(\mathrm{M}=3.19, \mathrm{SD}=0.910)$ (Table 3).

Table 3. Fans' Commitment, Support and Loyalty

\begin{tabular}{|l|c|c|}
\hline & Saudi Matches & EU Champions League \\
\hline Mean & 3.19 & 2.95 \\
\hline Std. Deviation & 0.910 & 1.108 \\
\hline Total & $\mathbf{1 , 5 0 6}$ & $\mathbf{1 , 5 0 6}$ \\
\hline
\end{tabular}

Source: By authors.

A further exploration shows that EU Champion league viewers are mostly fans of different football clubs that always watch their team. Their percentages are given in Table 4.

Table 4. EU Champion League Viewers

\begin{tabular}{|l|c|}
\hline $\begin{array}{l}\text { Saudi Football } \\
\text { Leagues }\end{array}$ & $\begin{array}{c}\text { Percentage who will always watch EU Champion } \\
\text { league games }\end{array}$ \\
\hline EPL & $97.9 \%$ \\
\hline Bundesliga & $95.7 \%$ \\
\hline La Liga & $97.4 \%$ \\
\hline Series A & $88.6 \%$ \\
\hline Ligue 1 & $84.6 \%$ \\
\hline
\end{tabular}

Source: By authors.

The above tables show that the great majority of football fans prefer to watch European league matches. The maximum mean value was achieved by the category who "watch EU league matches" compared to the lower mean 
obtained by the category who "watch all Saudi League matches". This indicates that affiliation of fans with a particular team can also affect the fans' attendance at the stadiums.

\section{Discussion and Conclusions}

Going to the stadium is one of many options available for fans to watch national and international football matches. The factors that determine the motivation of fans to attend sporting events can influence the marketing strategy of a company. This study identified factors that affect fans' attendance at the football stadiums to watch SPL football matches.

The key factors affecting fans' attendance at the stadiums were explored in the study. Ten factors were included as key elements in the questionnaire. The results show that the most significant factors that influence fans' attendance are: stadium service, non-numbered seating arrangement, stadium environment and, less significantly, lack of respect between fans of opposing teams and nonavailability of online tickets. Wakefield and Sloan (1995) and Yusof and Lee (2008) produced similar findings showing that factors such as stadium services, facilities and numbered seating affected fans' motivation to go to stadiums. Given these findings, it is evident that stadium services and facilities are the main barriers preventing fans from attending SPL football matches at the stadium. The decision makers in sport organisations in the KSA are working hard to develop the environment of stadiums and are working towards building new stadium models in different cities. This will motivate fans to attend matches at the stadiums.

The new stadiums are expected to increase the number of fans in attendance and, thus, football club revenues. In addition, the results show that there are external factors which might affect fans' attendance such as the possibility to watch EU league matches. A large number of respondents reported always watching EU leagues matches. This finding supports Alshalash's (2013) work who showed that the fans' rate of attendance at the European League was affected by favourite teams' matches. Consequently, this factor might be reducing fans' attendance at stadiums as most SPL matches are played at the weekend at the same time as EU league matches. In addition, the findings of the study also demonstrated that televised matches do affect the fans' attendance at the stadium. This result is in concordance with the outcomes of several studies in this aspect (Borland and MacDonald 2003, Buraimo et al. 2009, 2010). In addition, the SLS report's findings show team performance, commitment and loyalty of fans to their football as being important factors influencing the fans' attendance at the stadium in the KSA. This shows that football clubs in the KSA need to concentrate on hiring quality players to improve their performance and thus attract loyal and committed fans to their football teams (SLstat n.d.).

These results need to be taken into account by sport organisers and football clubs in the KSA in order to formulate a strategy for attracting 
audiences to watch football matches at the stadiums. Although the advent of TV is considered as a factor which negatively influences the fans' attendance at the stadium, SPL organisers can use this platform to advertise their matches to the fans in order to increase the fans' attendance, as suggested by Mustafa et al. (2014). In this way, television viewership can be used to improve the branding of SPL, which can lead to a continuous increase in the fan numbers at the stadiums. This fact needs to be considered at the strategic level by the boards in SPL, which can increase the ability of the league to widen its fan base and ensure that external factors are taken into account before any attempt is made to improve the rate of fans' attendance at stadiums.

\section{References}

Alghamdi T (2013) Numbers: The Reluctance of The Fans' Attendance to Stadiums is Growing and the Solution in the Hands of Saudi Football Federation. Retrieved from http://www.alriyadh.com/848430. [Accessed: 5 February 2015]

Allan G, Roy G (2008) Does television crowd out spectators? New evidence from the Scottish Premier League. Journal of Sports Economics 9: 592-605.

Alsenaidy AM, Ahmad T (2012) A review of current state M-government in Saudi Arabia. Global Engineers and Technologists Review 2(5): 5-8.

Alshalash O (2013) Non-attendance of fans lose the matches its enjoyment. Retrieved from http://www.okaz.com.sa/new/issues/20130906/Con20130906635310.htm. [Accessed: 6 February 2015]

Baimbridge M, Cameron S, Dawson P (1995) Satellite broadcasting and match attendance: The case of rugby league. Applied Economics Letters 2(10): 343-346.

Baroncelli A, Lago U (2006) Italian football. Journal of Sports Economics 7(1): 1328.

Beech J, Chadwick S (2004). The Business of Sport Management. Pearson Education.

Borland J, MacDonald R (2003) Demand for sport. Oxford Review of Economic Policy 19: 478-502.

Buraimo B, Forrest D, Simmons R (2009) Insights for clubs from match attendance in football. Journal of the Operational Research Society 60: 147-55.

Buraimo B, Paramio JL, Campos C (2010) The impact of televised football on stadium attendances in English and Spanish league football. Soccer and Society 11(4): 461-474.

Dietl H, Hasan T (2007) Pay-TV versus Free-TV: A model of sports broadcasting rights sales. Eastern Economic Journal 33(3): 405-428.

Fallahi A, Asad H, Khabiri M (2011) The comparison of the importance of the factors affecting spectators' attendance in football matches in Iranian professional league within age groups. World Journal of Sport Sciences 4(2): 159-165.

Foster WM, Washington M (2009) Organizational structure and home team performance. Team Performance Management: An International Journal 15(3/4): $158-171$.

García J, Rodríguez P (2002) The determinants of football match attendance revisited empirical evidence from the Spanish football league. Journal of Sports Economics 3(1): 18-38.

Hoye R, Smith A, Nicholson M, Stewart B, Westerbeek H (2012) Sport Management Principles and Applications ( $3^{\text {rd }}$ edn.). Oxon: Routledge (p. 43). 
Jumaah M (2014) Ten reasons behind the reluctance of fans for football stadiums. Retrieved from http://www.alraimedia.com/Articles.aspx?id=538272. [Accessed: 3 February 2015]

Kuypers T (1996) The Beautiful Game? An Econometric Study of Why People Watch English Football. Discussion Paper, University College, London Department of Economics.

Madani TA, Al-Mazrou YY, Al-Jeffri MH, Al-Huzaim NS (2004) Epidemiology of the human immunodeficiency virus in Saudi Arabia: 18-year surveillance results and prevention from an Islamic perspective. BMC Infectious Diseases 4(1): 25.

Mehus I, Osborn G (2010) Consuming football: The Norwegian experience, the English impact, and the possibilities of interdisciplinary research. Scandinavian Sport Studies Forum 1: 89-113.

Mustaffa MS, Nazarudin MN, Yosof B, Wahab SA, Razak MRA (2014) Malaysian ethnic groups and the culture of football fan attendance during EPL clubs friendly matches in Malaysia. Journal for Educational Thinkers 5: 185-202.

SLstat (n.d). Fan attendance statistics in the KSA Retrieved from http://www.slstat.com/spl2014-2015ar/index.php. [Accessed: 14 March 2015].

Szymanski S (2005) Handbook on the Economics of Sport. Edward Elgar Publishing.

Wakefield KL, Sloan HJ (1995) The effects of team loyalty and selected factors on spectator attendance. Journal of Sport Management 9: 153-172.

Withey S (2013) Fan Motivation for Attendance to Men's Division I College Soccer Matches. Master Thesis, Clemson University.

Yusof A, Lee HS (2008) Spectator perceptions of physical facility and team quality: a study of a Malaysian Super League soccer match. Research Journal of International Studies 8: 132-140. 
